\title{
Regional identity in the minds of young people in Siberia and the Far East
}

\author{
D. A. Kazantsev ${ }^{1}$, D. A. Kachusov ${ }^{1}$
}

${ }^{1}$ Altai State University, 61 Lenin Ave., Barnaul 656049, Russian Federation

DOI: $10.18255 / 2412-6519-2021-2-134-145$

Research Article

Full text in Russian

Currently, in both Russia and the world, the globalization is extending. The worldwide information field is in the process of formation, and many developed communities are going through blurring. At the same time, the new reasons for people to unite into the groups are arriving, and new communities tend to appear. The dynamic development of such term as identity had created numerous approaches and ways to define it, based on social, cultural and psychological peculiarities. The situation is common, in which the individuals that exist in the same social environment own many different identities, forming their bonds according to their needs. The problem of identity in Russia in particular is nevertheless acute, remaining open to discussion. The regions of the Russian Federation are more diverse due to the natural and territorial differences, as much as historical and social ones. Thus, Siberia and Far East are much more different than the European part of Russia in terms of social, ethnical and cultural aspects, therefore, the self-presentation of people also tends to differ. The goal of this research is to find the dominating identity among the student youth of Siberian and Far Eastern Federal Districts, to estimate the correlations in different types of identity, to shape the whole picture of self-identification among school and university students. The mass sociological study provides the objective and precise data on value-based cultural orientation inside the community under study, and to collect massive data for further analysis. The results of this research are to help and define the local specifics regarding social-political self-identification.

Keywords: regional identity; self-identification; the youth; students; crisis of identity; the Russians; region; distinctness

INFORMATION ABOUT THE AUTHORS

$$
\begin{array}{r|l}
\begin{array}{r}
\text { Kazantsev, Dmity A. } \\
\text { (correspondence author) }
\end{array} & \begin{array}{l}
\text { E-mail: dimkazanchev@mail.ru } \\
\text { Graduate, senior lecturer }
\end{array} \\
\text { Kachusov, Dmitry A. } & \begin{array}{l}
\text { E-mail: dmitrij.kachusov@mail.ru } \\
\text { Senior lecturer }
\end{array}
\end{array}
$$

Funding: RFBR, project 20-011-31061.

For citation: Kazantsev D. A., Kachusov D. A. Regional identity in the minds of young people in Siberia and the Far East // Social'nye i gumanitarnye znanija. 2021. Vol. 7, No 2. P. 134-145. (in Russ.)

(C) Kazantsev D. A., Kachusov D. A., 2021

This is an open access article under the CC BY license (https://creativecommons.org/licenses/by/4.0/) 


\title{
Региональная идентичность в сознании молодежи Сибири и Дальнего Востока
}

\author{
Д. А. Казанцев ${ }^{1}$, Д. А. Качусов ${ }^{1}$ \\ ${ }^{1}$ Алтайский государственный университет, пр. Ленина, 61, Барнаул, 656049, Российская Федерация \\ DOI: $10.18255 / 2412-6519-2021-2-134-145$ \\ Удк 32.019 .52 \\ Научная статья \\ Полный текст на русском языке
}

В настоящее время в России и мире углубляется процесс глобализации, формируется общемировое информационное пространство, происходит постепенное размывание многих уже сформированных сообществ. В то же время возникают новые основания для объединения людей и новые социальные общности. Динамическое развитие явления идентичности породило множество подходов к ее определению, базирующихся на различных основаниях социального, культурного, психологического характера. Повсеместно можно наблюдать ситуацию, когда существующие в одной социальной среде индивиды разделяют множество разных идентичностей, формируя привязанности согласно своим жизненным потребностям. Проблема идентичности в России также носит не менее глубокий характер и по сей день остается дискуссионной. Регионы Российской Федерации обладают большим разнообразием как в силу природно-территориальных, так и в силу исторических и социальных различий. Сибирь и Дальний Восток в значительной мере отличаются от европейской России по социальным, этническим и культурным характеристикам, соответственно, разнится и самопрезентация жителей данных регионов. Исследование призвано определить доминирующую идентичность в среде учащейся молодёжи Сибирского и Дальневосточного Федерального округа, рассмотреть соотношение в сознании различных типов идентичности, сформировать целостное представление о самоидентификации школьников и студентов. Массовое социологическое исследование позволяет наиболее объективно и точно взять срез ценностно-культурных ориентировок в сознании изучаемой социальной группы, получить большой объем материала для дальнейшего анализа. Результаты данного исследования должны помочь в установлении местной специфики в вопросе социально-политической самоидентификации.

Ключевые слова: региональная идентичность; самоидентификация; молодежь; школьники; кризис идентичности; россияне; регион; самобытность

\section{ИНФОРМАЦИЯ ОБ АВТОРАХ}

Казанцев, Дмитрий Анатольевич $\mid$ E-mail: dimkazanchev@mail.ru

(автор для корреспонденции)

Качусов, Дмитрий Анатольевич $\mid$ E-mail: dmitrij.kachusov@mail.ru

Старший преподаватель кафедры политологии

Финансирование: РФФИ, проект № 20-011-31061 «Модели и траектории политической идентификации школьников и студентов регионов РФ в условиях информационного общества (на примере регионов СФОИДФО)».

Для цитирования: Казанцев Д. А., Качусов Д. А. Региональная идентичность в сознании молодежи Сибири и Дальнего Востока // Социальные и гуманитарные знания. 2021. Том 7, № 2. С. 134-145.

(C) Казанцев Д. А., Качусов Д. А., 2021

Статья открытого доступа под лицензией СC BY (https://creativecommons.org/licenses/by/4.0/) 


\section{Введение}

В настоящее время процессы информатизации, глобализации, рост уровня мобильности и плотности социальных связей приводят к трансформации всех сфер жизни человечества. Буквально в пределах одного поколения изменяется социальнокультурная структура даже традиционных обществ, представления о положении человека в обществе и мире. Процессы общей глобализации, особенно заметные в развитых странах, вызвали к жизни кризис традиционных оснований идентичности. В то же время увеличение числа сетевых связей на низовом уровне, появление новых оснований для объединения приводит к появлению целого ряда «новых идентичностей», которые накладываются друг на друга и переплетаются друг с другом.

В России кризис идентичности проявился в не меньшей степени, в том числе и в связи с радикальным изменением принципов организации экономической и политической жизни, перекройкой территориальных рамок государства в начале 90-х гг. $\mathrm{XX}$ в., изменением статуса страны в системе международных отношений. Важными проявлениями идентификационного кризиса в России выступают мировоззренческий раскол общества, продолжающиеся поиски национальной идеи, адекватной новым социально-экономическим условиям, разрушение сложившейся структуры социально-пространственной идентичности.

Нередко в силу вышеозначенных причин на первый план выдвигается вместо национальной или государственной идентичности ее менее масштабный эквивалент - локальная или региональная идентичность. Она проявляется в самоотождествлении человека со своей малой родиной, с местом проживания, является важным психологическим компенсатором размывания ценностных ориентиров. Региональная идентичность позволяет поддерживать необходимые для самоидентификации человека эмоциональные или символические опоры. Данный процесс может идти как сознательно, так и неосознанно, как противовес размытым и непонятным ориентирам «глобального мира».

Прежде всего идентичность рассматривается учёными как социально-культурный феномен, сочетание индивидуального и коллективного действия, позиционирование себя относительно других индивидов и групп. Российский исследователь В. А. Ядов указывает, что основной механизм социальной идентификации - это сопоставление взглядов, ценностей, оценок, интересов, моделей поведения своей и враждебной группы. Однако он отмечает динамизм и множественность социальных взаимосвязей в современном обществе, а также возросшее ввиду перманентных кризисов и нестабильности стремление индивидов к групповой идентификация и солидарности. Это вызывает к жизни феномен сосуществования множества идентичностей, происходит «демократизация идентичности», индивид признает за собой и другими право выбирать свою идентичность и самостоятельно солидаризироваться одновременно с несколькими группами и общностями. Идентичности разного уровня и основания могут существовать одновременно, хотя можно выявить их иерархичность $[1$, c. 39].

Л. В. Смирнягин характеризует идентичность как основание самосознания индивида, как восприятие им социальной действительности, ассоциация себя с определенной группой на основании общности интересов и признаков. Он также говорит о многослойности и «перекрывании» различных идентичностей, которые могут выбираться самим индивидом и находиться в разных формах взаимосвязи [2, с. 34-35, 37]. 
Л. М. Дробижева под идентификацией понимает интерактивные процессы, через которые осуществляется самопонимание и возникает коллективная солидарность. Она происходит в процессе взаимодействия, коммуникации, конфликтов между сообществами различного уровня и фактором, способствующим интеграции и консолидации больших сообществ [3, с. 39-41]. Б. С. Ерасов, исследуя вопросы идентичности второй половины XX в., отмечал нарастание в них значения социокультурных факторов в ущерб «материальным». Он считает, что термин «самобытность» больше подходит для изучения вопросов самоопределения граждан и отождествления себя с определенной социальной группой или средой, к тому же он связан с понятиями «традиция», «специфика» и пр. Термин «идентичность» более узкий и обозначает внутреннюю определенность и самосознание личности или общности [4, с. 281-282].

В концепции Г. Брейкуэлла идентичность рассматривается как динамический социальный продукт взаимодействия памяти и сознания. Исследователь подчеркивает социальное происхождение идентичности, она рассматривается как соотношение личностной и социальной, причем первая - точка в процессе развития последней. Но личностная идентичность может влиять на социальную, поскольку они взаимодействуют и развиваются на протяжении всей жизни человека в соответствии с изменениями социального контекста [5, с. 19-20, 28-29]. Р. Брубейкер и Ф. Купер также рассматривают идентичность в динамике как процесс интерактивного развития коллективного самосознания. Она - продукт социального или политического действия, формирующий феномен коллективной солидарности внутри определенной группы. Идентичность - явление не статичное и многоаспектное, на котором основываются коллективное сознание и коллективное поведение, поэтому исследователи предлагают для ее описания термины, указывающие на это: самопонимание, социальная локализация, связанность, общность и т. д. [6, с. 17, 43-44].

Исследователь М. П. Крылов определяет региональную идентичность как социокультурный феномен, систему социальных отношений, строящуюся вокруг понятия «малая родина» и включающую два основных компонента: «местный патриотизм» и «пространственная самоидентификация». Исследователь подчеркивает, что в России местная идентичность носит «глубинный» характер, являясь характеристикой ментальности человека, его мировосприятия и мировоззрения [7, с. 13, 18-19]. Р. Ф. Туровский также связывает региональную идентичность с групповым сознанием локальных сообществ, отмечая, что в России главной проблемой исследования остается пространственная «привязка» идентичностей, так как для различных социальных общностей характерна своя локализация. Он указывает, что чаще всего региональная идентичность опирается на принадлежность к территориально-административным единицам [8, с.94-95]. Оба исследователя указывают, что в России не сложилось т. н. «исторических провинций» с развитым своеобразием, региональная идентичность долгое время подавлялась, происходила унификация внутренних культурных различий в рамках нации, и в настоящее время предпосылки для ее формирования довольно призрачные.

Позиция ряда авторов по вопросу понимания идентичности отталкивается от социально-психологических определений. Российский исследователь В. Г. Морогин рассматривает идентичность как «архетипический комплекс», систему социально обусловленных установок. Данные конструкты наполняются потребностным содержанием отдельных индивидов, социальных групп или этносов, служа маркерами принадлежности к определенной общности [9, с. 250-251]. Н. Н. Анисимова 
также характеризует идентичность с социально-психологических позиций и указывает, что данный термин более широкий, чем «самобытность». Это сложный конструкт, который представляет собой сочетание самобытности (т. е. индивидуальности, уникальности) и самосознания. Самосознание, в свою очередь, - отражение самобытности в сознании реального социокультурного субъекта [10, с. 64].

Е. В. Еремина определяет идентичность как сложное психосоциальное состояние, отражающее отождествление индивидом себя с сообществом, его понимание принадлежности к определенной целостности. Региональная идентичность - это гармоничное сочетание индивидуальных особенностей отдельной личности и ее включенности в локальные социумы. Также исследователь отдельно выделяет более узкое понятие «региональная идентификация», отражающее динамический процесс формирования и функционирования собственно идентичности [11, с. 311-312].

Определение идентичности дается также через понятие «чувство места», которое существует и в иностранной, и в отечественной исследовательской литературе. Британский географ Т. Крессуэлл [12, с. 72, 75-76] и российский исследователь Ю. А. Жердева [13, с. 10-11] рассматривают понятие «чувство места», или «sense of place», понимая «место» не как точку в пространстве, а как социальный конструкт. «Чувство места» обозначает реакцию индивида на его окружение, его способность ассоциировать себя с локальными сообществами и группами. Значение «чувства места» в социальной жизни в том, что оно возникает посредством создания взаимосвязей, как реальных, так и символических. Место проживания вызывает у жителей сходные переживания, что выражается в эмоционально окрашенных реакциях него и связанных с ним образов.

3. Бауман также указывает, что идентичность места формируется за счет чувства привязанности к месту - комплекса связей, образованных общностью проживания, культуры, языка и т. д. Здесь важна не только принадлежность к определенной территории, но и возможность человека идентифицировать себя, получать опыт совместного сосуществования, укреплять связи внутри своего сообщества. Идентичность места и чувство общности с локальной группой, по мнению автора, создают у индивида ощущение безопасности и чувство свободы [14, с. 175-176, 187-188].

Процессы атомизации и эрозии традиционных оснований групповой общности в современном мире вызывают к жизни представление об утрате актуальности прежнего понимания идентичности и критериев ее выделения. В этой связи становятся актуальны теории конструирования идентичности, сформулированные И. Гофманом, Б. Андерсеном, и И. Нойзманом. И. Гофман указывает на «внешнюю» направленность самоидентификации, под ней он понимает процесс репрезентации индивидов по отношению к другим людям, позволяющий защититься от «стигматизации» - приписывания себе негативных характеристик. Принятие определенной идентичности это способ оказать влияние на мнение окружающих о себе и найти ту общность, в которой человек не будет чувствовать себя ущемленным [15, с. 15-18].

Б. Андерсон вообще называет все социальные объединения людей, кроме первобытных, воображаемыми, так как они формируются на основе определенного образа общности. Соответственно, возникает идентичность только в процессе взаимодействия с другими членами сообщества и сторонними группами [16, с. 47-49]. И. Нойманн подчеркивает, что коллективные идентичности можно рассматривать только в связи с социальным окружением, где и формируются отличительные черты, позволяющие отграничить субъект от «других». Идентичность по своей природе - 
продукт межгруппового взаимодействия, и ее возникновение, изменение и поддержание тесно связаны с взаимоотношениями с другими субъектами [17, с. 67-68].

Исследователи П. Бергер и Т. Лукман указывают, что в настоящее время самоидентификация является не только инструментом внутренней рефлексии индивида, но и призмой, через которую он рассматривает и оценивает свое бытие. Более того, идентичность в современном мире выступает фактором, который способен воздействовать даже на жизнь человека в обществе, его связи и действия и таким образом изменять объективные социальные структуры. Идентичность обеспечивает смысловое наполнение повседневности индивида: «Это мир, создающийся в их мыслях и действиях, который переживается ими в качестве реального» [18, с. 17].

Множественность социальных субсистем, к которым может принадлежать современный человек, приводит к росту числа идентичностей, которые он разделяет. В связи с этим российские исследователи Г. М. Галмагова и М. Н Кокаревич обращаются к концепции Х. Койпа, который предложил понятие «лоскутная идентичность» (patchwork-identity), концентрируясь на повседневной деятельности по выстраиванию идентичности. Идентичность рассматривается как личный проект, в котором человек упорядочивает для себя фрагменты опыта собственной активности. Лоскутную идентичность следует понимать как открытый постоянный процесс, происходящий на протяжении всей жизни человека, отличительной особенностью которой является многополярность [19, с. 55-56].

Распространение интернет-сервисов для межличностного общения порождает разнообразные трансформации идентичности. Глобальная сеть представляет огромные возможности для яркой и уникальной самопрезентации, а также позволяет частично изменить сведения о себе и даже сконструировать новую сетевую идентичность для каждого нового случая. Виртуальная реальность дает индивиду возможность сформировать идеальный образ себя, даже если он не совместим с реальным [20, с. 122-123]. Чтобы отразить несогласованность идентичностей физического лица и виртуального образа, вводятся новые, «сетевые» или «виртуальные» их понимания, например, «сетевая идентичность», «виртуальная идентичность», «мобильная идентичность», «электронная идентичность» [21, с. 5].

Конструктивистский подход к пониманию идентичности разделяет отечественный исследователь Г. Л. Тульчинский. Основной единицей современного глобализирующегося общества становится личность как видоизменяемый и не статичный проект, который может быть результатом как собственных усилий, так и коммуникационного воздействия других субъектов. Несмотря на то, что это не приводит к отказу от сложившейся системы ролевых идентификаций, роли становятся прежде всего средством, используемым для формирования себя как «бренда». Идентификационная специфика индивида или группы выражается через формирование многочисленных связей и образов, а самоидентификация становится не конечной целью, а инструментом для реализации личностного потенциала [22, с. 88-89].

Таким образом, подходы к определению региональной идентичности и выявлению ее наиболее базовых оснований довольно разнообразны. Исследователи отталкиваются от различных ее характеристик, рассматривая данное явление как динамический процесс формирования коммуникационных связей в рамках определенной территории; как аналог «самобытности» - наличия уникальных социально-культурного особенностей различных социальных групп; как социально-психологический феномен общности с локальными сообществами; как сознательно конструируемую индивидами характеристику социальной реальности. Можно дать 
обобщенное определение понятию «региональная идентичность» - это характеристика сознания и поведения, основанная на комплексе взаимодействующих и взаимосвязанных компонентов социального, культурного и психологического характера, отражающих привязанность индивида к определенному региону, где он проживает или проживал, и связанных с ним социальных общностей. Кроме того, крайне важно помнить, что региональная идентичность является приобретаемой и не является взаимоисключающей - она может успешно сосуществовать с другими видами идентичности.

\section{Методы}

Как мы видим, проблема идентичности в общественных науках является актуальной в наше время и находится в центре внимания исследователей. Сибирь и Дальний Восток представляют особый интерес для изучения в силу сложности этнокультурного ландшафта и разницы в экономико-географическом положении составных частей исследуемого региона. Также при обращении к этим территориям нельзя не заметить асимметричности в развитии региональных политических систем, из-за чего в рамках одной страны можно наблюдать различные их модели и различные типы гражданского поведения. Отталкиваясь от заявленной тематики работы и теоретической базы по тематики идентичности, можно сформулировать ряд задач, на которые нужно дать ответы в ходе исследования.

Во-первых, необходимо определить, какой тип идентичности превалирует в сознании учащейся молодежи, проживающей на исследуемой территории. Также необходимо уточнить, с каким уровнем социальных структур (нация, регион, макрорегион и др.) связывается идентичность и можем ли мы вообще говорить о наличии региональной идентичности.

Во-вторых, ввиду наличия в исследуемом регионе разных типов субъектов Федерации представляется необходимым определить наличие или отсутствие различий в картине самоидентификации населения национальных (республики) и административно-территориальных (края и области) образований.

В-третьих, дать ответ, существует ли зависимость между представлениями о собственной идентичности и социально-демографическими (пол, возраст, регион проживания) и ценностно-политическими предпочтениями опрошенных респондентов. Данная задача позволит оценить причинно-следственные связи, влияющие на формирование идентичности молодежи, а также ее динамику у разных возрастных групп.

Дать ответы на поставленные задачи возможно только на основании обширного эмпирического материала. В этих целях в сентябре-октябре 2020 г. был проведен очный опрос учащейся молодежи средних и высших образовательных учреждений методом квотного, гнездового анкетирования. Совокупность выборки составляет 2409 человек - учащихся 8-11 классов школ и студентов 1-2 курсов вузов, из них - 1271 мужчин, 1138 женщин. Опрос проводился в 11 субъектах Сибирского федерального округа и Дальневосточного федерального округа Российской Федерации, как национально-территориальных - Республика Алтай, Республика Тыва, Республика Бурятия (384 респондента), так и административно-территориальных - Новосибирская область, Иркутская область, Кемеровская область, Красноярский край, Алтайский край, Приморский край, Камчатский край, Забайкальский край (2025 респондентов). 
Поиск и выделение признаков идентичности произведены путем выделения в анкетах респондентов «ответов-маркеров», связанных с тематикой самоидентификации индивидов. Для обработки полученных статистических материалов использовалась программа SPSS, полученные результаты при необходимости визуализировались в графическом виде.

\section{Результаты}

На вопрос «Кем вы себя в большей степени ощущаете?» (выбор респондентом до 3 вариантов ответа) 1200 опрошенных ответили «россияне» (49,81\% от общего числа), 924 опрошенных (38,36 \%) выбрали вариант «Сибиряком/Жителем Дальнего Востока», 752 опрошенных выбрали вариант «Жителем своего города (района)» $(31,22 \%)$. Далее «Гражданином мира» идентифицируют себя 669 респондентов $(27,77 \%)$, «Жителем своего региона» - 552 респондента $(22,91 \%)$, «Представителем своего этноса (русский, украинец и т. п.)» - 476 респондентов (19,76 \%), «Представителем своей конфессии» - 142 респондента (5,89\%), вариант «Другое» выбрал 71 человек $(2,95 \%)$.

Если отслеживать зависимость между делением респондентов по полу и их идентификационными предпочтениями, то придется отметить, что не наблюдается устойчивой связи. Исключение составляет случай с идентификацией себя «Жителем своего города (района)», где разница показателей с делением по полу составляет около 3,5 \% от средней, что демонстрирует диаграмма на рис. 1.

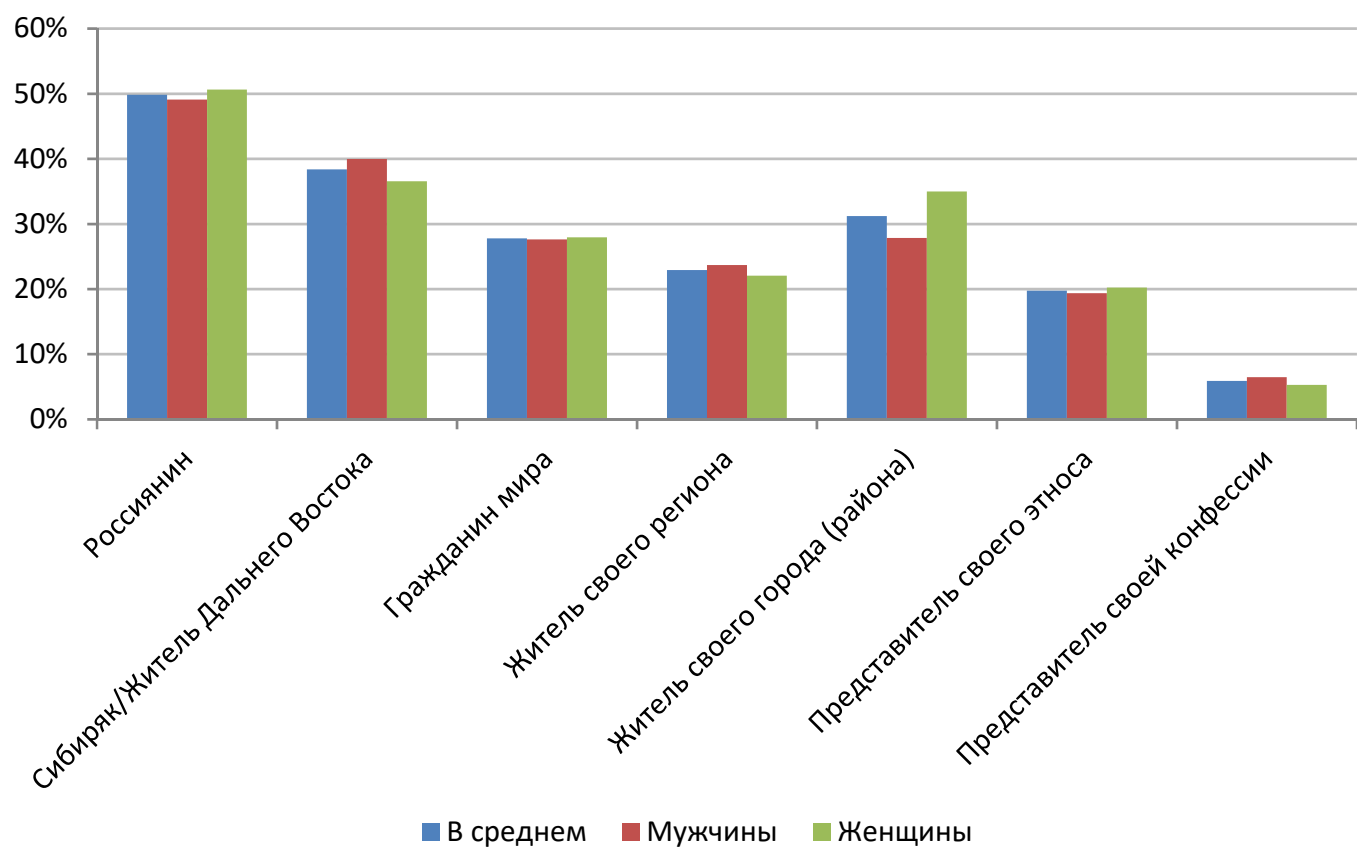

Рисунок 1. Распределение идентификационных предпочтений школьников 8-11 классов и студентов 1-2 курса СФО и ДВО. 
Связь между возрастными характеристиками (8-11 классы, 1-2 курс вузов) опрошенных респондентов и их идентификационными предпочтениями демонстрируется на рисунке 2. В целом выраженной связи между возрастными изменениями опрошенных респондентов и динамикой выбираемой ими идентификации не наблюдается, однако можно выявить несколько особенностей, которые наглядно демонстрирует график. Во-первых, необходимо отметить постепенное повышение по мере взросления (от 8 класса к 2 курсу вуза) доли респондентов, идентифицирующих себя с макрорегионом - Сибирью или Дальним Востоком. От показателей 8, 9, 10 классов с данными 34,60 \%, 32,34 \% и 37,15 \% соответственно в 11 классе показатель изменяется на 42,08 \%, а в дальнейшем составляет 46,40 \% и 45,85 \% на 1 и 2 курсе. Во-вторых, значительно снижается процент отождествляющих себя с местом проживания (городом или районом) среди студентов вузов относительно школьников. Постепенное понижения уровня местной идентификации к выпускному классу в школе: $35,31 \%, 33,28 \%, 33,24 \%$ и 30,37 \% сменяется резким «провалом» на первом курсе университета, всего 21,94 \%), но вновь начинает расти на втором курсе $(28,06 \%)$. В-третьих, максимум идентификации себя как части своего этноса, с одной стороны, и «гражданина мира», с другой, приходится на 11 класс, возрастая в период обучения в школе и снижаясь в вузе.

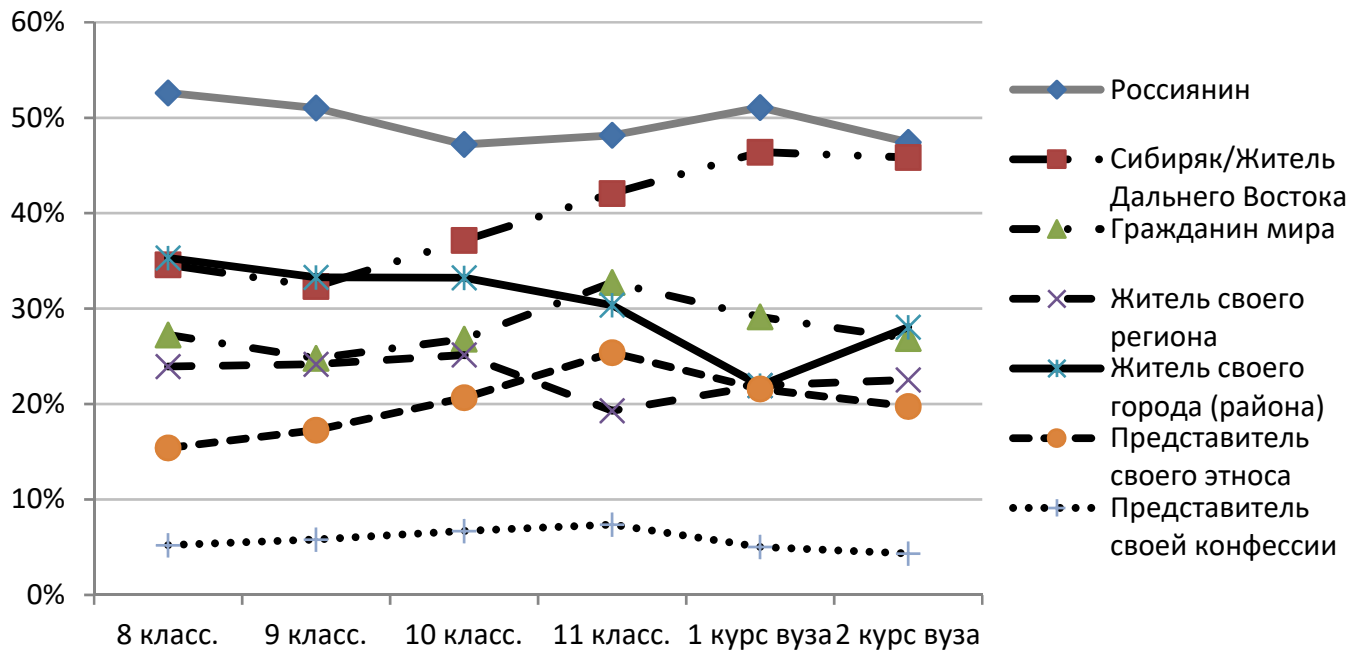

Рисунок 2. Возрастная динамика идентичности школьников 8-11 классов и студентов 1-2 курса СФО и ДВО.

Также следует рассмотреть ответы респондентов на вопрос «Назовите, что из перечисленного больше всего объединяет вас со всеми россиянами?». Большинство, 1088 опрошенных (45,16 \%), назвало главным объединяющим фактором «Государство». Далее респонденты поставили «Родной язык» - 871 человек (36,16 \%), «Родная земля, территория, природа» - 803 человека (33,33 \%), «Культура» - 653 человека $(27,11 \%)$, «Обычаи, праздники» - 583 человека $(24,20 \%)$, «Историческое прошлое» 575 человек $(23,87$ \%). Варианты «Ответственность за судьбу страны», «Общие символы (флаг, герб)», «Родственные и дружеские связи» и «Черты характера» выбрали, 
соответственно, 461, 457, 396 и 226 опрошенных, а 113 ответили, что «Ничего не объединяет».

Если просмотреть связь преобладающей идентификации с типом региона, в котором проживают респонденты, то необходимо выделить две основных группы субъектов: административно-территориальные и национальные единицы. В первых распределение доминирующих типов идентичности происходит в следующем порядке: «Россиянин» $(49,09$ \%), «Сибиряк/Житель Дальнего Востока» $(38,81 \%)$, «Житель своего города (района)» $(30,62 \%)$, «Гражданин мира» $(28,3 \%)$, «Житель своего региона» $(21,73 \%)$, «Представитель своего этноса» $(18,17 \%)$, «Представитель своей конфессии» $(5,98 \%)$ и «Другое» $(3,36 \%)$. В республиках картина распределения идентичностей следующая: «Россиянин» (53,65 \%), «Сибиряк/Житель Дальнего Востока» $(35,94 \%)$, «Житель своего города (района)» $(34,38 \%)$, «Житель своего региона» $(29,17 \%)$, «Представитель своего этноса» $(28,13 \%)$, «Гражданин мира» $(25,00 \%)$, «Представитель своей конфессии» (5,47 \%) и «Другое» $(0,78$ \%).

Таким образом, в республиках несколько выше, чем в краях и областях, уровень общегосударственной (россияне) и локальной (город/район) идентификации и ниже уровень отождествления себя с макрорегионами (Сибирью и Дальним Востоком) и с «гражданином мира». Значительная разница наблюдается в показателях самоидентификации по признаку принадлежности к региону и этнической группе в национальных субъектах данные показатели выше, чем в административных.

Ответы на вопрос о наиболее близких политических взглядах распределились следующим образом. Затруднилось ответить на этот вопрос 28,1 \% от общего числа опрошенных, вариант «смешанные» выбрали 23,1 \% респондентов, указали, что не имеют политических убеждений, 18,1\%. Четкие идеологические предпочтения имеет меньшее число опрошенных: социально-демократические - $10 \%$, либеральные - 10,7 \%, коммунистические - 4,5\%, анархистские - 1,8 \%, консервативные и националистические - по 1,5\%.

Анализ самых распространенных вариантов идентификации среди представителей различных идеологий демонстрирует следующие предпочтения. Среди коммунистов превалируют выбравшие вариант «Россиянин» (50,93\%), затем «Сибиряк/Житель Дальнего Востока» (41,67\%) и «Житель своего города (района)» $(27,78$ \%). Приверженцы социал-демократических воззрений чаще выбирают пункты «Россиянин» $(50,62$ \%), затем «Сибиряк/Житель Дальнего Востока» $(42,32$ \%) и «Гражданин мира» $(28,22$ \%). Среди сторонников либеральных взглядов большинство выбирает «Россиянин» $(42,80$ \%), затем «Сибиряк/Житель Дальнего Востока» $(37,74 \%)$ и «Гражданин мира» $(33,85 \%)$. Консерваторы прежде всего указывают в качестве предпочитаемых «Россиянин» $(61,11 \%)$, затем «Сибиряк/Житель Дальнего Востока» $(41,67 \%)$ и «Житель своего региона» $(27,78 \%)$.

Сторонники националистических воззрений чаще других выбирают «Россиянин» $(48,57 \%)$, затем «Гражданин мира» $(45,71 \%)$ и «Житель своего региона» $(42,86 \%)$, но как ни парадоксально, отождествляют себя с этносом всего 22,86 \% респондентов. Разделяющие идеологию анархизма в качестве самоидентификации указывают варианты «Сибиряк/Житель Дальнего Востока» (36,36 \%), затем «Россиянин» $(31,82 \%)$ и «Гражданин мира» $(29,55 \%)$. Люди со смешанными политическими воззрениями характеризуют себя как «Россиянин» $(51,35 \%)$, затем «Сибиряк/Житель Дальнего Востока» $(41,11$ \%) и «Гражданин мира» $(31,78$ \%). Следующие две категории респондентов демонстрируют схожую динамику представлений о собственной идентификации. Не имеющие политических предпочтений респонденты 
определяют свою идентичность как «Россиянин» $(48,97$ \%), затем «Житель своего города (района)» $(37,47$ \%) и «Сибиряк/Житель Дальнего Востока» $(36,32$ \%). Затруднившиеся ответить выбрали варианты «Россиянин» $(52,37$ \%), затем «Сибиряк/Житель Дальнего Востока» $(38,61 \%)$ и «Житель своего города (района)» $(36,69 \%)$.

\section{Выводы}

По результатам анализа материала мы можем прийти к следующим выводам. Во-первых, со значительным преимуществом в сознании молодежи доминирует общероссийская идентичность, что вполне объясняется историко-культурными особенностями складывания российского общества, когда данный тип идентичности формировался преимущественно по отношению к остальным. Подтверждает данный тезис и то, что в качестве объединяющего россиян фактора чаще всего называют вариант «государство», независимо от политических предпочтений (кроме анархистов).

Во-вторых, развитие региональной идентичности в республиках выше, чем в ненациональных территориальных единицах, наблюдается гораздо более высокий уровень идентификации на основании принадлежности к региону и этнической группе. Данный факт, очевидно, является следствием особенностей этнонациональной структуры и условий жизни исследуемых регионов.

B-третьих, мы видим, что число опрошенных, идентифицирующих себя как жители Сибири и Дальнего Востока, превышает число тех, кто связывает свою идентичность с субъектом Федерации. Это указывает, что региональная идентичность связана не с субъектом Федерации, как указывал ряд отечественных исследователей, а с макрорегиональными территориальными структурами, своего рода «историческими провинциями» России - Сибирью и Дальним Востоком.

В-четвертых, можно выделить возрастную динамику показателей идентичности у школьников старших классов и студентов. Происходит постепенное повышение по мере взросления доли респондентов, идентифицирующих себя с надрегиональным уровнем, одновременно в студенчестве значительно снижается процент отождествляющих себя с местом проживания (городом или районом) относительно школьников.

B-пятых, существует связь между идеологическими предпочтениями молодежи и их идентичностью, например, представители консервативных взглядов идентифицируют себя как россиян чаще, чем представители либеральных и анархистских взглядов, в то же время «анархисты» и «либералы» чаще говорят о себе как о «человеке мира», чем консерваторы или коммунисты.

\section{Ссылки / References}

1. Ядов В.А. Социальная идентификация в кризисном обществе // Социологический журнал. 1994. № 1. С. 35-51.

2. Смирнягин Л. В. О региональной идентичности // Пространство и время в мировой политике и международных отношениях: материалы 4 Конвента РАМИ. В 10 т. / Под ред. А. Ю. Мельвиля. Т. 2. М.: МГИМО-Университет, 2007. С. 81-107.

3. Дробижева Л. М. Российская идентичность: поиски определения и динамика распространения // Социологические исследования. 2020. № 8. С. 37-50.

4. Ерасов Б. С. Цивилизации универсалии и самобытность. М: Наука, 2002. 524 с. 
5. Breakwell M. Coping with threatened identities. London; New York: Methuen, 1986. 222 p.

6. Brubaker R. Ethnicity without groups. Hoboken: Wiley, 2003. 296 p.

7. Крылов М. П. Региональная идентичность в Европейской России. М.: Новый хронограф, 2010. $240 \mathrm{c}$.

8. Туровский Р. Ф. Региональная идентичность в современной России // Российское общество: становление демократических ценностей? / Моск. центр Карнеги; под ред. М. Макфола и А. Рябова. М.: Гендальф, 1999. С. 87-136.

9. Морогин В. Г. Психологическая концепция идентичности // Сибирский педагогический журнал. 2011. № 11. С. 233-253.

10. Анисимова Н. Н. Культурная, национальная и цивилизационная идентичность // KANT. 2019. №2 (31). C. 163-167.

11. Еремина Е. В., Ретинская В. Н. Региональная и гражданская идентичность: взаимосвязь и механизмы формирования // Социально-гуманитарные знания. 2016. №9. С. 310-317.

12. Cresswell T. Place: A short introduction. Oxford, 2009. 153 p.

13. Жердева Ю. А. Чувство места как категория социальной памяти // Международный журнал исследований культуры. 2015. № 2. С. 5-11.

14. Бауман 3. Индивидуализированное общество / Пер. В. Л. Иноземцева. М.: Логос, 2005. 390 c.

15. Гофман И. Стигма: Заметки об управлении испорченной идентичностью / Пер.

M. С. Добряковой // Высшая школа экономики: сайт. [2021]. URL:

https://www.hse.ru/data/2011/11/15/1272895702/Goffman_stigma.pdf (дата обращения: 26.02.2021).

16. Андерсон Б. Воображаемые сообщества: размышление об истоках и распространении национализма / Пер. с англ. В. Николаева. М.: Кучково поле, 2016. 416 с.

17. Нойманн И. Использование Другого: образы Востока в формировании европейских идентичностей. М.: Новое издательство, 2004. 336 с.

18. Бергер П., Лукман Т. Социальное конструирование реальности. Трактат по социологии знания / Пер. Е. Руткевич. М.: Медиум, 1995. 323 с.

19. Галмагова Г. М., Кокаревич М. Н. Типология форм социокультурной идентичности // Векторы благополучия: экономика и социум. 2018. № 3 (30). С. 48-60.

20. Солдатова Е. Л., Погорелов Д. Н. Феномен виртуальной идентичности: современное состояние проблемы // Образование и наука. 2018. Т. 20. №5. С. 105-124.

21. Лысак И. В., Косенчук Л. Ф. Формирование персональной идентичности в условиях сетевой культуры. М.: Спутник +, 2016. 147 с.

22. Тульчинский Г. Л. Идентичность как проект: Условия политического позиционирования личности // Символическая политика: сборник научных трудов / Под ред.

О. Ю. Малинова. Вып. 5: Политика идентичности. М.: ИНИОН РАН, 2017. С. 80-97. 